\title{
Brown adipose tissue and lipid metabolism imaging
}

Citation for published version (APA):

Paulus, A., van Marken Lichtenbelt, W., Mottaghy, F. M., \& Bauwens, M. (2017). Brown adipose tissue and lipid metabolism imaging. Methods, 130, 105-113. https://doi.org/10.1016/j.ymeth.2017.05.001

Document status and date:

Published: 01/11/2017

DOI:

10.1016/j.ymeth.2017.05.001

Document Version:

Publisher's PDF, also known as Version of record

Document license:

Taverne

Please check the document version of this publication:

- A submitted manuscript is the version of the article upon submission and before peer-review. There can be important differences between the submitted version and the official published version of record.

People interested in the research are advised to contact the author for the final version of the publication, or visit the DOI to the publisher's website.

- The final author version and the galley proof are versions of the publication after peer review.

- The final published version features the final layout of the paper including the volume, issue and page numbers.

Link to publication

\footnotetext{
General rights rights.

- You may freely distribute the URL identifying the publication in the public portal. please follow below link for the End User Agreement:

www.umlib.nl/taverne-license

Take down policy

If you believe that this document breaches copyright please contact us at:

repository@maastrichtuniversity.nl

providing details and we will investigate your claim.
}

Copyright and moral rights for the publications made accessible in the public portal are retained by the authors and/or other copyright owners and it is a condition of accessing publications that users recognise and abide by the legal requirements associated with these

- Users may download and print one copy of any publication from the public portal for the purpose of private study or research.

- You may not further distribute the material or use it for any profit-making activity or commercial gain

If the publication is distributed under the terms of Article $25 \mathrm{fa}$ of the Dutch Copyright Act, indicated by the "Taverne" license above, 


\title{
Brown adipose tissue and lipid metabolism imaging is
}

\author{
Andreas Paulus $^{\mathrm{a}, \mathrm{d}, *}$, Wouter van Marken Lichtenbelt ${ }^{\mathrm{b}}$, Felix M. Mottaghy ${ }^{\mathrm{c}, \mathrm{d}}$, Matthias Bauwens ${ }^{\mathrm{a}, \mathrm{c}}$ \\ a Department of Radiology and Nuclear Medicine, NUTRIM School for Nutrition and Translational Research in Metabolism, Maastricht University, Maastricht, The Netherlands \\ ${ }^{\mathrm{b}}$ Department of Human Biology \&' Human Movement Sciences, NUTRIM School for Nutrition and Translational Research in Metabolism, Maastricht University Medical \\ Center, Maastricht 6200 MD, The Netherlands \\ ${ }^{\mathrm{c}}$ Department of Medical Imaging, Division of Nuclear Medicine, MUMC, Maastricht, The Netherlands \\ ${ }^{\mathrm{d}}$ Division of Nuclear Medicine, Uniklinikum Aachen, Aachen, Germany
}

\section{A R T I C L E I N F O}

\section{Article history:}

Received 30 November 2016

Received in revised form 28 April 2017

Accepted 5 May 2017

Available online 19 May 2017

\section{Keywords:}

Adipose tissue imaging

Lipid metabolism

Nuclear imaging

Optical imaging

MRI

\begin{abstract}
A B S T R A C T
Purpose: Brown adipose tissue (BAT) research has evolved from an underestimated to a fast developing field. Its assumed curing properties for the world wide epidemic obesity, and its related diseases, makes this tissue an interesting target for a broad amount of non-invasive molecular BAT tracers. Apart from ${ }^{18} \mathrm{~F}$-FDG PET/CT there are several methods to detect BAT and measure its metabolism in a more appropriate way. Especially interesting is the measure of lipid turnover, because fatty acids comprise the main fuel for active BAT. This review outlines different imaging modalities suitable for BAT imaging with the overall goal to explain the yet not completely understood mechanism in BAT and its quantitative contribution to whole body lipid and energy metabolism.

Methods: Publications with focus on brown adipose tissue and lipid metabolism imaging are analyzed, different imaging approaches are introduced and promising BAT tracers are presented.

Results: Radiolabelled and fluorescent fatty acids, labelled particles, ${ }^{3} \mathrm{H}$-Triolein and ADIFAB staining can give information about the inflow and therefore about the utilization of fatty acids which represents the activation state in vivo/in vitro. Non-invasive scanning with CT or MRI is a useful addition to those techniques.

Conclusion: Lipid metabolism imaging offers the opportunity to visualize and quantify yet undiscovered aspects of BAT metabolic activities and is key to completely clarify its role in whole body lipid and energy metabolism.
\end{abstract}

() 2017 Elsevier Inc. All rights reserved.

\section{Contents}

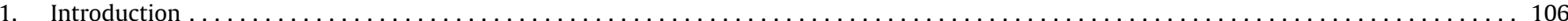

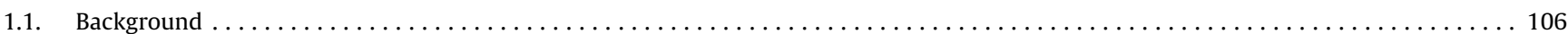

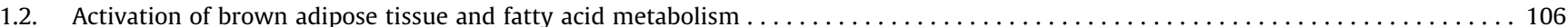

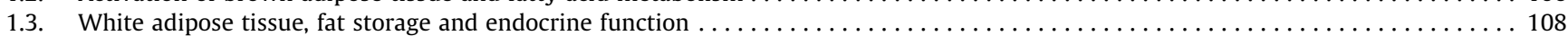

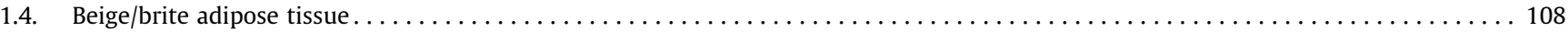

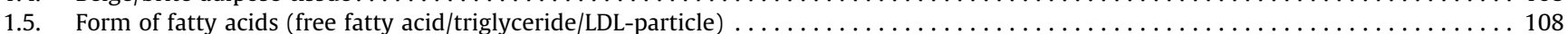

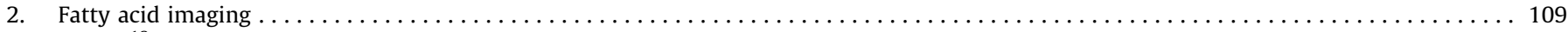

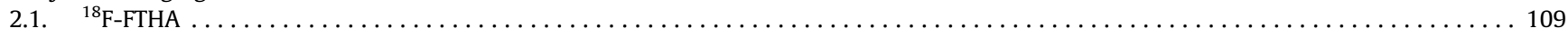

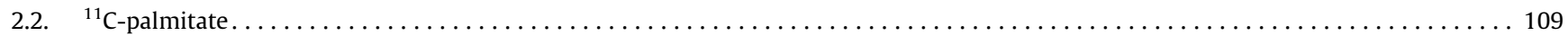

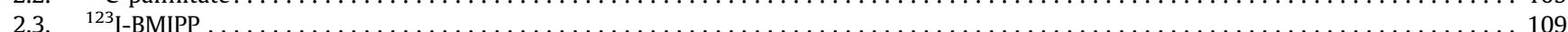

Abbreviations: BAT, brown adipose tissue; WAT, white adipose tissue; PET, positron emission tomography; FDG, 2-fluor-2-desoxy-D-glucose; LCFA, long chain fatty acids; FA, fatty acids; TG, triglycerides; UCP1, uncoupling protein 1; TRLs, triglyceride-rich lipoproteins; LPL, lipoprotein lipase; FTHA, 14(R,S)-fluoro-6-thia-heptadecanoic acid; Cpalmitate, C-hexadecanoic acid; BMIPP, 15-(4-iodophenyl)-3-methyl-pentadecanoic acid.

This work was supported by the Weijerhorst Foundation.

* Corresponding author at: Department of Radiology and Nuclear Medicine, NUTRIM School for Nutrition and Translational Research in Metabolism, Maastricht University, Maastricht, The Netherlands.

E-mail address: andreas.paulus@maastrichtuniversity.nl (A. Paulus). 


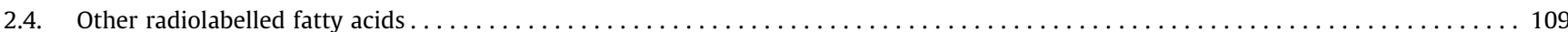

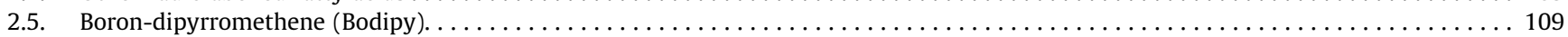

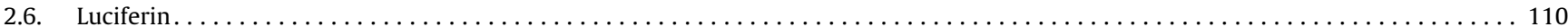

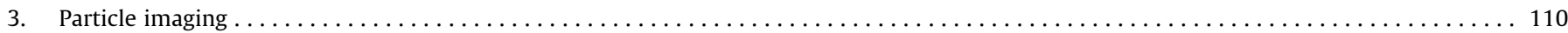

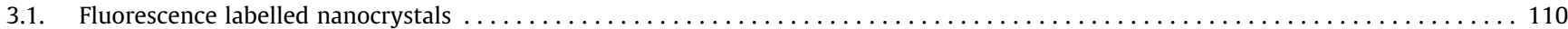

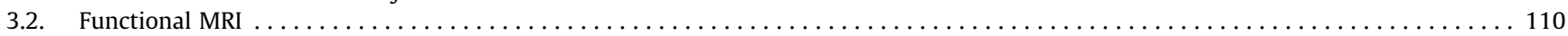

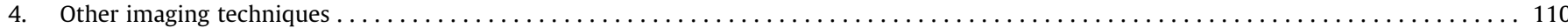

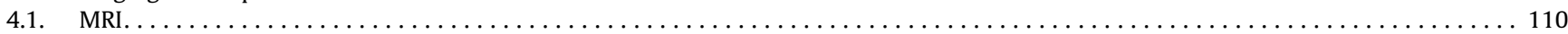

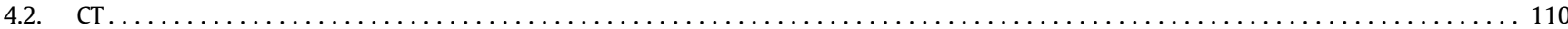

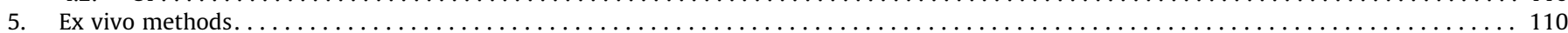

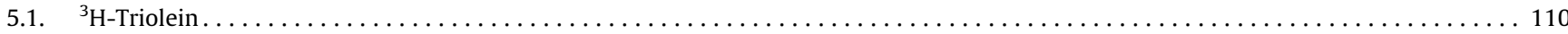

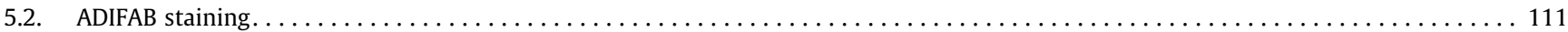

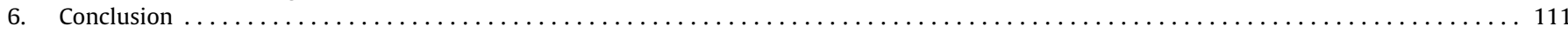

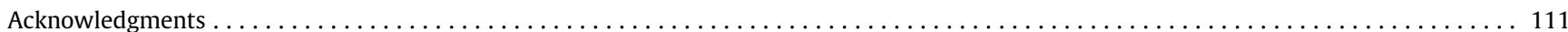

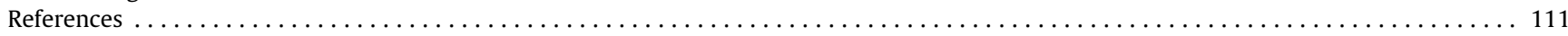

\section{Introduction}

\subsection{Background}

The function and presence of BAT in adults was neglected until two decades ago. Now the investigation of BAT using molecular imaging has matured to one of the most interesting and fast developing research topics in endocrine research. Because obesity - and its related metabolic syndrome - is reaching epidemic proportions in the western world [1] and may even become a more severe problem in the near future for the worldwide population, more attention is drawn to adipose tissue metabolism. A turning point was the discovery that WAT, apart from storing energy (fat), is able to secret leptin, an important hormone controlling the energy balance [2]. Other substances [3] (autocrine and endocrine) released by WAT have been found and by that the consideration of the impact of adipose tissue on whole body metabolism rose continuously. In retrospective PET studies with FDG, it could be shown that besides WAT, another form of adipose tissue exists in adult humans [4-6]. In these studies, symmetrical accumulations of FDG appeared in the supraclavicular region, which were originally thought to be attributed to uptake in cervical muscles. Later, scans with PET/CT indicated that these "artifacts" correlate with Hounsfield units of fat [6]. By these FDG studies it could be proven that BAT is functionally present in adults and is metabolically active. BAT, named after its darker color resulting from higher mitochondria expression within the cell and increased blood circulation [7], was previously thought to be absent in adult humans and only be present in newborns to maintain their body temperature [8]. The results of the PET scans indicate a chance of observing BAT in 5-8\% of standard clinical routine PET scans $[4,9]$ and a total contribution to body mass of $0,05-$ $0,01 \%$ [10]. These findings could be confirmed later by dedicated cold exposure studies where a direct correlation between cold exposure and BAT metabolic activity, measured through FDG uptake, was reported [11-13]. Assuming a fixed relative contribution of glucose and fatty acids and that mainly fatty acids and glucose contribute to energy expenditure [12,14], an increase in metabolic activity of BAT would result in an increase of total body energy expenditure of 2-28\% [15]. Therefore activation of BAT with unchanged food uptake, may lead to significant weight loss, offering an additional treatment option to obese patients. Another field of application would be in patients with pheochromocytoma. It was found that catecholamine secreting tumors activate BAT and lead to an increase in metabolic activity characterized by FA and glucose uptake [16-18]. In these studies BAT activity was inversely correlated to body mass index and in general patients with cancer cachexia are often suffering from body weight loss and depletion of muscular and adipose tissue [19].
However, in order to actually calculate the metabolic activity of BAT in humans, in addition to FDG PET/CT, other tracers and techniques are needed. Through the upcoming interest in this tissue, several new activation, targeting and imaging strategies have been developed to visualize BAT's functions. FDG has set the stage; several attributions of BAT have been defined. Non-invasive visualization of lipid metabolism could give more insight since lipid turnover is one of the major features of BAT. This review summarizes early as well as the newest inventions of lipid metabolism imaging linked to BAT and describes how visualization of lipid fate and adipose tissue activity has evolved.

\subsection{Activation of brown adipose tissue and fatty acid metabolism}

First observations of BAT in humans were performed with FDG [4-6] which visualizes metabolic active tissue in terms of glucose uptake. It was observed that through cold exposure the chance of visualizing BAT increased in animals and lean subjects [11-13]. Besides, it was shown that BAT is activated through norepinephrine binding to $\beta 3$-adrenoeceptor $[20,21]$. Recently it was observed for the first time that BAT takes up an increased amount of glucose in obese humans after cold acclimation. This led to the conclusion that significant amounts of BAT can be recruited during repeated cold exposure [22]. Glucose is mainly taken up by protein transporters of the GLUT family, mainly the fat muscle specific isoform GLUT4 $[23,24]$. Glucose is processed in different pathways e.g. in citric acid cycle [25] or it is conversed to FA [26,27]. Nevertheless LCFA are the main "fuel" for BAT. Tracers based on fatty acids, quantify the metabolic activity of BAT in a better way than glucose does.

Through the norepinephrine activation process FA stored as TG in lipid droplets are consumed in the mitochondria to produce heat and new FA are taken up [28,29]. This identifies FA as the main metabolized substance in BAT and makes them and other compounds targeting lipid metabolism a powerful tool to visualize BAT and its functions within the body.

Usually mitochondria oxidize fatty acids and ATP is produced to store the nascent energy but BAT mitochondria contain the BAT specific UCP1 which gives them the ability to uncouple the oxidation process and to produce heat instead of ATP [30-33]. This process is responsible for nonshivering thermogenesis [15,34]. Fedorenko et al. showed that LCFA ( $>12$ carbon atoms [35]) are essential for the uncoupling process as they work as a carrier for $\mathrm{H}^{+}$through the UCP1 and that LCFA are also produced within the inner mitochondria membrane by PLA2 [36]. In BAT cells UCP1 is inhibited by purine nucleotides, mainly ATP. The UCP1 channel is blocked by the nucleotides from the cytosolic side [37-40]. It was shown that LCFA can overcome the blocking of UCP1 and 


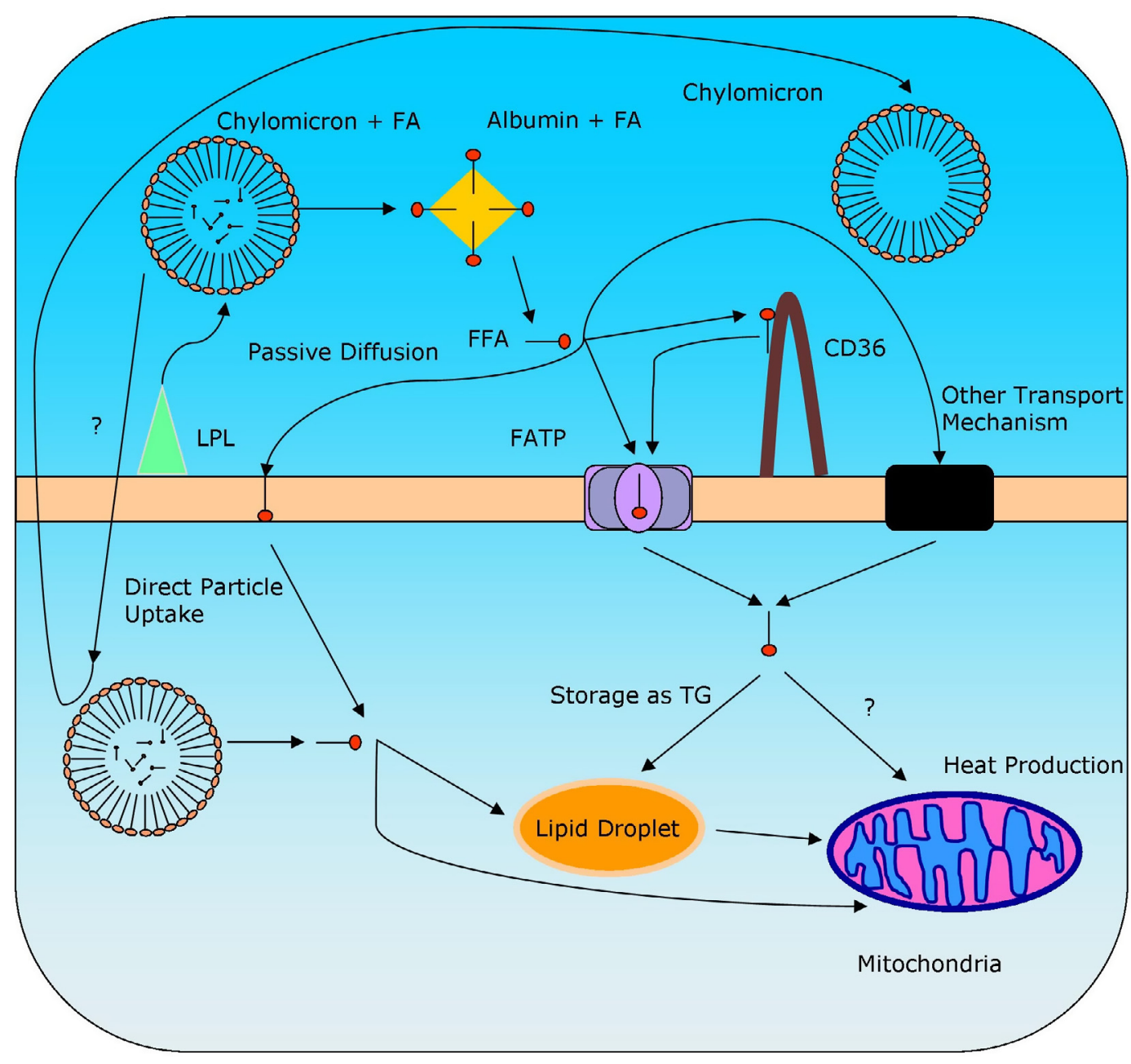

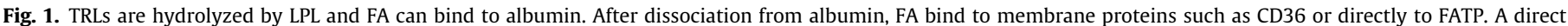

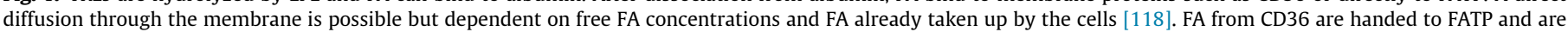

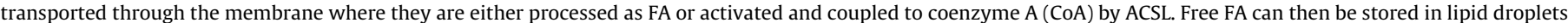
as TG after esterification or directly processed in the mitochondria.

support the activation of the uncoupling process [15,36,41]. Activation through LCFA also confirms the observation that lipolysis activates thermogenesis in the same order of magnitude than norepinephrine does $[42,43]$.

As quoted before, stored TGs in BAT can be utilized for combustion or FA can be taken up after lipolysis by BAT. Uptake of FA from external sources by a brown adipocyte is realized by protein mediated transport [44], nevertheless the exact mechanism of FA uptake is unclear. FA are transported in TRLs by the blood. BAT uptake of FA via internalization of these particles, via direct FA uptake after lipolysis related breakup of TRLs or a combination of both is possible. Khedoe et al. equipped TRLs of different size with ${ }^{3} \mathrm{H}$-oleate and ${ }^{14} \mathrm{C}$-cholesteryl oleate [45]. At room temperature a lipolysis supported uptake could be observed as cholesteryl oleate stays within the particle core due to its hydrophobicity and most taken up activity in BAT resulted from ${ }^{3} \mathrm{H}$-oleate. Left over remnant particles, containing a higher ratio of ${ }^{14} \mathrm{C}$-cholesteryl oleate are cleared by the liver which explains why a much higher ${ }^{14} \mathrm{C}$-activity compared to ${ }^{3} \mathrm{H}$-activity can be observed in the liver. Also cold exposure or thermoneutrality did not promote internalization of TRLs in BAT cells in an important amount but of course changed the amount of FA taken up by BAT [45].

In contrast to these experiments is the finding of Bartelt et al. They labelled TRLs with ${ }^{3} \mathrm{H}$-oleate and hydrophobic ${ }^{59} \mathrm{Fe}-\mathrm{SPIO}$ nanocrystals [46]. As a result of lipolysis ${ }^{3} \mathrm{H}$-oleate can enter the cell whereas ${ }^{59} \mathrm{Fe}$-SPIO nanocrystals stay inside of the TRL's. In cold exposed mice a significant faster clearance of ${ }^{3} \mathrm{H}$-oleate and ${ }^{59} \mathrm{Fe}-$ SPIO and a tenfold higher uptake of both imaging agents in BAT is reported. Through intravital microscopy a rapid attachment to the endothelium, followed by an internalization of the TRLs could be observed [46]. Bartelt et al. explain their observations that through lipolysis products the endothelial barrier function is decreased and TRLs can enter the cell [47].

The discrepancy between both experiments may be explained by different imaging agents used and therefore different uptake mechanisms are needed to explain the results. Nevertheless, the dominant uptake mechanism (lipolysis assisted uptake of FA or internalization of TGLs) is not determined at the moment and needs to be established by other imaging approaches and experiments.

In terms of lipolysis, LPL is the first of multiple proteins involved in the process of FA uptake into BAT [29,48,49]. Other important proteins related to FA uptake of BAT are fatty acid translocase (FAT/CD36) [50], fatty acid transport proteins (FATPs) [51] and fatty acyl-CoA synthetases (ACSL) [52]. The common way of FA uptake is described as in Fig. 1, according to [48].

Different studies have identified LPL and CD36 as indispensable factors for FA uptake and a loss of one of these proteins results in 
an impaired adipose metabolism leading to hypertriglyceridemia, increased glucose uptake and hypothermia during fasting and cold exposure $[53,54]$.

LCFA can also be produced through lipogenesis within the cell by fatty acid synthase up to a carbon chain length of 16 carbon atoms [29]. Elongation to very long chain fatty acids is done by very long chain fatty acids enzymes (ELOVL) where ELOVL3 was found to be overexpressed in cold exposed BAT and mice lacking of ELOVL3 where only able to survive cold by shivering thermogenesis [55]. These findings indicate lipogenesis as an essential feature to ensure the TG amount necessary during cold exposure.

Its high amount of mitochondria and multilocular lipid droplets make BAT appear more like muscle than adipose tissue [15].

\subsection{White adipose tissue, fat storage and endocrine function}

The main function of WAT is fat storage and fatty acid secretion. When energy intake is higher than consumption, fatty acids are stored in WAT. In times of fasting or cold exposure, WAT is activated to release its fuel (fatty acids) by stimulation of lipolysis through the sympathetic nervous system [56]. Through the 90s of the last century the interest in WAT changed from a tissue only responsible for energy storage to a tissue that also takes part in body metabolism. Its physiological role has changed through the discovery of the first protein secreted from WAT: leptin [2]. More and more proteins have been discovered that are responsible for different functions in the body $[3,57,58]$. Leptin e.g. is the critical hormone in energy balance and is produced principally by white fat, giving the tissue an endocrine function. Other proteins are: angiotensinogen, adipsin, acylation-stimulating protein, adiponectin, retinol-binding protein, tumor necrosis factor $\alpha$, interleukin 6 , plasminogen activator inhibitor- 1 and tissue factor. These proteins can work as inflammatory cytokines, some influence the lipid metabolism and others are involved in vascular haemostasis [59].

\subsection{Beige/brite adipose tissue}

A special type of adipose tissue is the so called beige (or brite) adipose tissue. Characteristics of the white adipocyte are a large lipid droplet and a small amount of mitochondria. BAT has multiple small lipid droplets, its transcriptional profile is similar to skeletal muscle cells [60] and BAT has a large amount of mitochondria which overexpress UCP1. Beige adipocytes can differentiate in vivo from WAT or WAT precursor cells through activation processes (e.g. $\beta 3$-adrenergic receptor agonists) and then contain multiple lipid droplets and express UCP1 within their mitochondria, which potentially makes them an important player in increasing energy expenditure and fighting against obesity [61]. This clusters of beige cells appear e.g. through prolonged cold exposure in WAT depots close to noradrenergic nerve fibers which trigger the beige adipocyte recruitment [62]. Typically norepinephrine is released from the sympathetic nerves and activates adipocyte (brown and beige) thermogenesis. This process normally induces UCP1 expression through phosphorylation of PPARy coactivator 1alpha and other activators $[63,64]$. Sidossis et al. investigated the hypermetabolism in patients with burn injuries and found increased circulating levels of epinephrine and norepinephrine as well as elevated expression of UCP1 in the according WAT-areas as a result of adrenergic stress [65]. This proves that epinephrine and norepinephrine are responsible for browning of WAT which makes this tissue able to participate in the process of non-shivering thermogenesis. Alternatively, M2 macrophages are recruited to subcutaneous WAT during cold exposure and secret catecholamines to activate WAT browning $[66,67]$. Irisin, an exercise-induced myokine, can also induce browning of WAT $[68,69]$. This paradox finding could be shown in vitro and in vivo [68] and it has been hypothesized that this mechanism evolved from shivering muscle contraction to support non-shivering thermogenesis by an increase in BAT volume and has thereby a therapeutic potential to treat obesity $[68,69]$. Another important player in WAT browning is cancer cachexia. Through tumor-derived parathyroid hormone-related protein (PTHrP) WAT browning is promoted and more energy is needed in a Lewis lung cancer model [70]. Deactivation of PTHrP inhibits WAT browning and prohibits energy wastage [70]. Besides of the listed factors for browning there are also environmental factors, endocrine hormones and transcriptional mediators which can cause browning of WAT [62]. Beige adipose tissue cells are only temporarily available for thermogenesis as they develop back to WAT-cells after activation. By other studies it could be confirmed that beige adipocytes almost reached UCP1 levels of BAT and that beige fat mitochondria are thermogenically active [60].

\subsection{Form of fatty acids (free fatty acid/triglyceride/LDL-particle)}

The main suppliers of FAs taken up by BAT are TRLs (i.e. chylomicrons or very-low-density-lipoprotein-particles) circulating in the blood [71]. After incorporation into adipocytes, FAs are stored as TGs in lipid droplets. Lately LPL-activity was found to be important for whole body TGL clearance through BAT and WAT $[46,72]$. Savonen et al. recently found a correlation between LPL distribution and type of tissue where the FA are taken up and identified LPL as a mandatory binding side for LDL particles to be processed (lipolysis with exposure of FA) [73]. a)

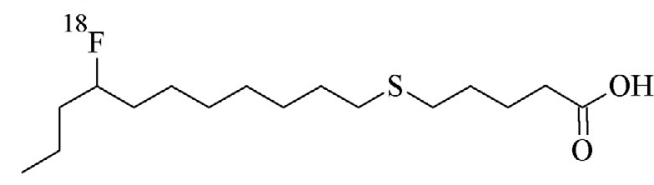

c)

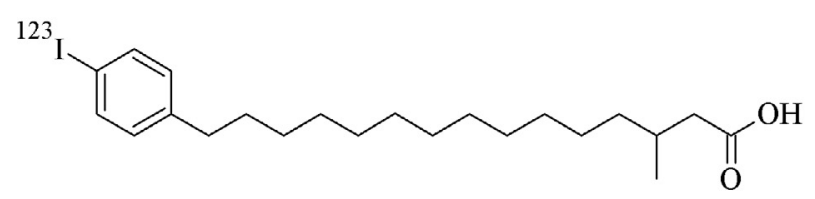

b)<smiles>CCCCCCCCCCCCCCCC(=O)O</smiles>

d)

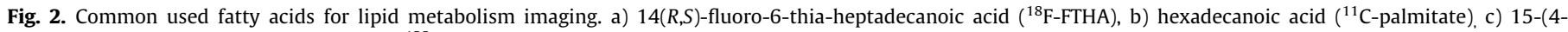
iodophenyl)-3-methyl-pentadecanoic acid ( ${ }^{123}$ I-BMIPP), d) 4,4-Difluoro-5,7-Dimethyl-4-Bora-3a,4a-Diaza-s-Indacene-3-Hexadecanoic Acid (BODIPY-C 16 ). 


\section{Fatty acid imaging}

As already mentioned, fatty acids are the main metabolized substance in BAT. For this reason they are used as tracers to visualize adipose tissue and its metabolism.

\section{1. ${ }^{18}$ F-FTHA}

FTHA (Fig 2a)) was developed as a myocardial imaging agent because a high amount of LCFA is processed in the tricarboxylic acid cycle. It can be labelled by ${ }^{18} \mathrm{~F}$ through isotope exchange which makes this compound an easily available PET imaging agent. It is $\beta$-oxidized in the mitochondria and is bound irreversible to mitochondria proteins once the sulphur group is free [74]. Maximal uptake of FTHA is similar to ${ }^{11} \mathrm{C}$-palmitate showing that neither the sulphur atom at the sixth position nor the introduction of ${ }^{18} \mathrm{~F}$ has influence on the uptake kinetics [75,76]. 13F3THA analog showed significant lower uptake and faster washout, betaoxidation is completely blocked by the sulphur atom at the odd position of 13F3THA [77,78]. Radioactivity taken up by BAT was specific to only the even-substituted thia-FTHA and transport and metabolism steps are hindered for 13F3THA because the carboxyl group and the sulphur are located very close to each other. The fatty acid is internalized through assistance of several binding proteins in the endothelial, interstitial, and intracellular spaces [75]. A similar mechanism for BAT as for WAT can be assumed which makes this compound suitable for BAT imaging. In first attempts of imaging BAT with ${ }^{18}$ F-FTHA Ouellet [79] could show increased FA uptake in combination with an elevated ${ }^{11} \mathrm{C}$-acetate uptake, as an oxidative tissue marker and therefore metabolism indicator, in cold exposed humans. Additionally a higher ${ }^{18} \mathrm{~F}$-FDG uptake was reported indicating a higher energy turnover as a result of a higher metabolic activity during cold exposure [79]. CT gave information about the lipid density, which indicates the amount of intracellular TGs, and a utilization of these stored TG identifies them as the main fuel during cold exposure. These observations are in agreement with findings in other animal models $[79,80]$.

\section{2. ${ }^{11} \mathrm{C}$-palmitate}

Another important PET tracer is ${ }^{11} \mathrm{C}$-palmitate (Fig 2b)). Its short half life of $20 \mathrm{~min}$. makes an in-house cyclotron mandatory which restricts its use significantly. Apart from that restriction palmitate would be the optimal choice with respect to binding affinity as no big bulky chelator molecule needs to be coupled for imaging purposes. It behaves like any other natural non-synthesized fatty acid, justifying why it is always compared to modified molecules as a gold standard [81]. ${ }^{11} \mathrm{C}$-palmitate has been used as a myocardial imaging agent in clinical examinations [82-84] but as adipose tissue imaging becomes more and more important it is also used as a fat imaging agent in clinical experiments [85]. In comparison to BMIPP (see below) and FTHA this FA is fully metabolized and metabolism products including ${ }^{11} \mathrm{CO}_{2}$ are secreted by adipocytes which is decreasing the image quality.

\section{3. ${ }^{123} I-B M I P P$}

Like FTHA, BMIPP (Fig 2c)) started as a myocardial imaging agent [86]. It is labelled with ${ }^{123}$ I through an isotopic exchange reaction to produce a SPECT-imaging agent. Commercial availability of BMIPP (up to 2012) and ${ }^{123}$ I as well as the easy to perform exchange reaction [87] made this compound favourable for adipose tissue imaging. A dependence on the isomeric confirmation was shown by Lin et al. [86] and the [ $\left.{ }^{123} \mathrm{I}\right]-3(R)$-BMIPP version showed uptake suitable for clinical trials. This implies that internalization is not hindered by the bulky benzol ring at the end of the FA. In comparison with palmitic acid under fasting conditions, BMIPP had lower uptake into hepatocytes but similar characteristic changes were observed over time [81]. So far BMIPP has only been used by one group to image BAT and its protein contribution in FA uptake $[53,88]$.

\subsection{Other radiolabelled fatty acids}

As already mentioned, radiolabelled fatty acids have been often used as myocardial imaging agents in the past. The already described fatty acids have been shown good characteristics in terms of stability, binding affinity, pharmacokinetics etc. but there have been others developed which will be mentioned in the following paragraph.

Iodine-123-hexadecanoic acid (IHXA) and iodine-123 heptadecanoic acid (IHDA) have been developed as myocardial perfusion agents $[89,90]$. Clearance kinetics for both agents were compared with ${ }^{11} \mathrm{C}$-palimtate and a similar clearance was found for the fast clearance components. The slow clearance components differed in that way that the half time for IHXA and IHDA was only approximately one fourth of that of ${ }^{11} \mathrm{C}$-palimtate $[89,91]$. These two components represent $\beta$-oxidation and fatty acid storage in lipid pools. This fast elimination half time makes this compound unsuitable for SPECT as decreased image quality can be expected. In addition a deiodination process could be observed which requires special corrections to differentiate between myocardial and blood pool activity [92].

15-( $p$-Iodophenyl)-pentadecanoic acid (IPPA) showed a faster myocardial clearance compared to BMIPP making it unfavorable for SPECT as this results in image distortions and loss of quantitative image accuracy [92]. This problem is caused mainly because straight chain fatty acids are faster metabolized and cleared via $\beta$-oxidation. The methyl-group at the $\beta$-position of BMIPP slows down the oxidation process and improves clearance and image accuracy in that way [93].

\subsection{Boron-dipyrromethene (Bodipy)}

A different imaging approach is fluorescent imaging with Bodipy. Because of its hydrophobic properties, Bodipy dyes can be used for staining of lipids, membranes and other lipophilic substance classes. High fluorescence quantum yields can be achieved due to its wide spread $\pi$-electron system. Fluorescence of this molecule is achieved through excitation at $503 \mathrm{~nm}$ and emission at $512 \mathrm{~nm}$. The extension of the crude dye determines its field of usage for imaging purposes. There are many approaches from tumor imaging to adipose tissue detection with a fatty acid modified Bodipy. It has been proven that Bodipy C-16 (Fig. 2d)) binds specifically to fatty acid binding proteins [94] with a similar affinity as oleic acid, is incorporated into lipid droplets in hepatocytes [95], can be quantified by fluorescent cell scanners or plate readers [96] and can be followed downstream in metabolic processes after uptake [97]. In a first try we were able to visualize WAT and BAT with Bodipy-C16 specifically in vitro with a $2 \mu \mathrm{M}$ Bodipy C-16 solution (unpublished results), like already reported for hepatocytes [95]. Uptake could be identified as specific uptake as the lipid droplets were filled by Bodipy C-16 and no uptake in the cell nucleus can be observed. Incorporation of the fatty acid works as already described through protein mediation and the Bodipy dye does not hinder the uptake qualitatively. As penetration depth of excitation and emitted light cannot overcome the tissue barrier for BAT imaging, fluorescence imaging is restricted to in vitro applications in this approach. With its high spatial resolution it is a powerful tool to image on a cellular level $[94,96]$. 


\subsection{Luciferin}

By imaging adipose tissue with bioluminescence, problems of PET and SPECT imaging, like short half life and un-physiological uptake can be overcome [98]. To a non-esterified fatty acid probe a luciferine derivative is coupled via a disulfide linker. This disulfide bridge is stable outside of the cells [99] and through reduction by glutathione within the cell a thiol is produced which undergoes cyclization to release free luciferine [100]. Free luciferine is than converted to oxyluciferine and a photon of light by luciferase [101]. Henkin et al. investigated the imaging abilities of this compound and reported specific uptake as it could be blocked by oleate in vitro. Additionally luciferine uptake from micelles containing FAluciferine could be observed and BAT specific uptake in vivo could be proven as uptake could be increased through BAT stimulation [100].

\section{Particle imaging}

To image lipid metabolism there are also other pathways available apart from imaging FA. Some interesting approaches with indirect measures for FA uptake have been reported and will be described in this section

\subsection{Fluorescence labelled nanocrystals}

FA are mostly transported in TRLs through the body. At the moment there are two assumptions about the delivery of FA through TRLs. FA can be taken up by adipocytes after TRLs are lipolyzed outside of the cell [45] or TRLs are internalized before they are lipolyzed [46]. To investigate this process Bartelt et al. labelled TRLs with hydrophobic fluorescent nanocrystals (QD-TRL) [46]. Quantum dots (QD) have a broad excitation and a narrow emission range and are therefore best suited for fluorescence imaging [102]. With QD-TRLs an internalization of lipoproteins due to an increase in permeability of the endothelial barrier function could be observed [46]. Other applications of this imaging agent can be thought of for quantitative and qualitative lipoprotein incorporation.

\subsection{Functional MRI}

Similar to QD-TRLs, Bartelt et al. labelled lipoproteins with hydrophobic superparamagnetic ${ }^{59} \mathrm{Fe}$-oxide. The intention is the same as for QD-TGLs. The hydrophobic iron nanocrystals stay inside of the lipoprotein and indicate if the particle is incorporated or not. In addition the particle is filled with ${ }^{3} \mathrm{H}$-oleate to control whether FA are taken up. Bartelt et al. observed a faster clearance for the FA as well as for the nanocrystals after cold exposure indicating a contribution of BAT. Total oleate and Fe-oxide concentrations in cold activated mice of BAT and liver were comparable and omitting cold exposure lead to a decrease in BAT uptake for both. These results and the fact that ${ }^{59} \mathrm{Fe}$-oxide concentrations were still increased one week after injection indicate an internalization of the whole lipoprotein particle [46].

In contrast to these observations, the study of Khedoe et al. is indicating an extracellular lipolysis followed by protein mediated uptake of FA [45].

\section{Other imaging techniques}

\section{1. $M R I$}

With the possibility to image with a very high resolution and no radiation dose for the patient, MRI is an important player in adipose tissue imaging. By measuring the lipid content in interscapular BAT (iBAT), Grimpo et al. investigated the response to cold exposure and noradrenaline stimulation for wild type and UCP1 knock-out mice. Lipid content was the same for both groups under all temperature conditions with less FA stored in lipid droplets after cold exposure. A faster noradrenaline response could be observed in wild type mice [103]. Additionally in the study of Holstila et al. MRI was identified as a more adequate method to identify and quantify BAT, independently of its activation state, compared to PET/CT with ${ }^{18}$ F-FDG. BAT masses calculated with PET/CT were significant smaller than the masses obtained through dissection. MRI provided more accurate information even if a small overestimation has been observed. Advantageous is the independence of the activation state as this method is measuring the water/lipid content and compares it with previous records. For the same reason no cold exposure is necessary to activate BAT. A successful human pilot study was performed too by this group [104]. Additionally first studies have been done in adult humans with FDG-PET/CT as a reference standard by van Rooijen et al. [105]. In comparison to the mentioned studies in animal models [106-109], they could not discern active BAT on the basis of tissue fat content. Dynamic BAT activation could be identified by T2*-weighted MRI during cold stimulation. Even though PET provides images of active BAT with a higher contrast, MRI is capable in gaining additional information such as: temporal and quantitative measurements of tissue fat content, changes in blood flow, volume, and oxygenation of active BAT [105].

\section{2. $C T$}

A standalone computed tomography to identify BAT seems in terms of a lower radiation dose compared to PET/CT a good choice but without PET it is almost impossible to identify BAT by the difference in Hounsfield units and gets even more complicated when WAT is located next to it. So most of the recent studies are PET/CT related and some indicate PET/CT with ${ }^{18} \mathrm{~F}$-FDG not as the optimal choice [110]. Another problem is the difference in interpreting the Hounsfield units as adipocytes. Gortel et al. used a threshold of -200 to -30 , Maurovic- Horvat et al. used a threshold from -149 to -30 and Mahabadi et al. a threshold of -195 to -45 [111-114]. By having this differences an under or overestimation is easily possible and does not really describe the amount of BAT. Because of the listed reasons a CT on its own is not capable in identifying BAT and also a PET/CT with ${ }^{18} \mathrm{~F}$-FDG is not the best choice anymore. There are several better compounds which target BAT without activation and also MRI seems to have more advantages and a more accurate way to identify adipocytes.

\section{Ex vivo methods}

\section{1. ${ }^{3}$ H-Triolein}

Tritium does not have the optimal properties for non-invasive imaging. Its really soft radiation makes it impossible to detect it from outside of the body because the emitted electrons are stopped after a few micrometers in tissue. Its field of application is supported by its favourable biodistribution and plasma extraction. By that method the uptake at certain time points can be tested by the fraction of Triolein still present in the blood $[46,76]$. An impact of cold exposure or BAT activation through noradrenaline can be observed but not a clear quantification of adipocyte uptake can be achieved as lipids can be taken up by other tissues or cleared from the blood.

${ }^{3} \mathrm{H}$-triolein is also used in autoradiography studies. Stein et al. investigated metabolism steps of starved rat fat cells and found 
that after exposure with ${ }^{3} \mathrm{H}$-triolein containing blood, $9-17 \%$ of the esterified fatty acids were in the form of diglycerides, less than $1 \%$ were monoglycerides and the rest were TG. They assumed therefore the esterification of diglycerides to TG as the rate limiting step in the TG synthesis in adipose tissue. Four fifth of the signals observed were found within the lipid droplets of the cell identifying them as the primary destination for newly taken up FA [115].

\subsection{ADIFAB staining}

ADIFAB is a stain for unbound fatty acids and is only applicable in in vitro work. Acrylodan labelled rat intestinal fatty acid binding protein (ADIFAB) is fluorescent if it is bound to a fatty acid. Kampf et al. [116] investigated the change in cytosolic unbound FA in response to a change in extracellular unbound FA. They discovered an influx concentration dependence of membrane carrier proteins which could be saturated and a strong influence of translocation for the fatty acid uptake ratio [116]. Other experiments have been done to examine the fatty acid uptake mechanism in vitro with ADIFAB and identified flip-flop as the rate limiting step for oleate transport through the lipid bilayer membrane [117].

\section{Conclusion}

Lipid metabolism imaging has a broad field of application. It is generally accepted in terms of myocardial imaging, hepatic imaging etc. Our focus was to outline its broad function in fields within the whole body and specifically for the use to visualize adipose tissue and its metabolism. Its fast developing field within the niche of adipose tissue imaging draws attention to new imaging approaches and agents and helps to understand more and more this, for a long term, underestimated tissue. We expect radiolabelled fatty acids to be the most promising agents in clinical research to unravel adipose tissue processes in BAT for the next years but also fluorescent imaging, with its ability to image on subcellular level, and MRI should not be underestimated and will contribute to the exploration of adipose tissue and lipid metabolism.

\section{Acknowledgments}

Conflicts of interest: The authors report no conflicts of interest. All authors have read the journal's policy on conflicts of interest. All authors have disclosed any financial or personal relationship with organizations that could potentially be perceived as influencing the described research. All authors have read the journal's authorship agreement. AP wrote the manuscript. All authors read and approved the final manuscript.

\section{References}

[1] J.M. Rippe, S. Crossley, R. Ringer, Obesity as a chronic disease: modern medical and lifestyle management, J. Am. Diet. Assoc. 98 (10 Suppl 2) (1998) S9-S15.

[2] Y. Zhang, R. Proenca, M. Maffei, M. Barone, L. Leopold, J.M. Friedman, Positional cloning of the mouse obese gene and its human homologue, Nature 372 (6505) (1994) 425-432.

[3] R.S. Ahima, J.S. Flier, Adipose tissue as an endocrine organ, Trends Endocrinol. Metab. 11 (8) (2000) 327-332.

[4] P. Lee, J.R. Greenfield, K.K.Y. Ho, M.J. Fulham, A critical appraisal of the prevalence and metabolic significance of brown adipose tissue in adult humans, Am. J. Physiol. Endocrinol. Metab. 299 (4) (2010) E601-E606.

[5] C. Cohade, K.A. Mourtzikos, R.L. Wahl, "USA-Fat": prevalence is related to ambient outdoor temperature-evaluation with 18F-FDG PET/CT, J. Nucl. Med. 44 (8) (2003) 1267-1270.

[6] T.F. Hany, E. Gharehpapagh, E.M. Kamel, A. Buck, J. Himms-Hagen, G.K. von Schulthess, Brown adipose tissue: a factor to consider in symmetrical tracer uptake in the neck and upper chest region, Eur. J. Nucl. Med. Mol. Imaging 29 (10) (2002) 1393-1398.

[7] C.M. Anderson, M. Kazantzis, J. Wang, S. Venkatraman, R.L.S. Goncalves, C.L. Quinlan, R. Ng, M. Jastroch, D.I. Benjamin, B. Nie, C. Herber, A.-A.N. Van, M.J.
Park, D. Yun, K. Chan, A. Yu, P. Vuong, M. Febbraio, D.K. Nomura, J.L. Napoli, M. D. Brand, A Stahl, Dependence of brown adipose tissue function on CD36mediated coenzyme Q uptake, Cell Rep. 10 (4) (2015) 505-515.

[8] J.M. Heaton, The distribution of brown adipose tissue in the human, J. Anat. 112 (Pt 1) (1972) 35-39.

[9] A.M. Cypess, S. Lehman, G. Williams, I. Tal, D. Rodman, A.B. Goldfine, F.C. Kuo, E.L. Palmer, Y.-H. Tseng, A. Doria, G.M. Kolodny, C.R. Kahn, Identification and importance of brown adipose tissue in adult humans, N. Engl. J. Med. 360 (15) (2009) 1509-1517.

[10] S. Enerbäck, Human brown adipose tissue, Cell Metab. 11 (4) (2010) 248-252.

[11] W.D. van Marken Lichtenbelt, J.W. Vanhommerig, N.M. Smulders, J.M.A.F.L. Drossaerts, G.J. Kemerink, N.D. Bouvy, P. Schrauwen, G.J.J. Teule, Coldactivated brown adipose tissue in healthy men, N. Engl. J. Med. 360 (15) (2009) 1500-1508.

[12] K.A. Virtanen, M.E. Lidell, J. Orava, M. Heglind, R. Westergren, T. Niemi, M. Taittonen, J. Laine, N.-J. Savisto, S. Enerbäck, P. Nuutila, Functional brown adipose tissue in healthy adults, N. Engl. J. Med. 360 (15) (2009) 1518-1525.

[13] M. Saito, Y. Okamatsu-Ogura, M. Matsushita, K. Watanabe, T. Yoneshiro, J. Nio-Kobayashi, T. Iwanaga, M. Miyagawa, T. Kameya, K. Nakada, Y. Kawai, M. Tsujisaki, High incidence of metabolically active brown adipose tissue in healthy adult humans: effects of cold exposure and adiposity, Diabetes 58 (7) (2009) 1526-1531.

[14] A.A.J.J. van der Lans, J. Hoeks, B. Brans, G.H.E.J. Vijgen, M.G.W. Visser, M.J. Vosselman, J. Hansen, J.A. Jörgensen, J. Wu, F.M. Mottaghy, P. Schrauwen, W. D. van Marken Lichtenbelt, Cold acclimation recruits human brown fat and increases nonshivering thermogenesis, J. Clin. Invest. 123 (8) (2013) 33953403.

[15] B. Cannon, J. Nedergaard, Brown adipose tissue: function and physiological significance, Physiol. Rev. 84 (1) (2004) 277-359.

[16] T. Puar, A. van Berkel, M. Gotthardt, B. Havekes, A.R.M.M. Hermus, J.W.M. Lenders, W.D. van Marken Lichtenbelt, Y. Xu, B. Brans, H.J.L.M. Timmers, Genotype-Dependent Brown Adipose Tissue Activation in Patients With Pheochromocytoma and Paraganglioma, J. Clin. Endocrinol. Metab. 101 (1) (2016) 224-232.

[17] P.V. Joshi, V.R. Lele, Unexpected visitor on FDG PET/CT-brown adipose tissue (BAT) in mesentery in a case of retroperitoneal extra-adrenal pheochromocytoma: is the BAT activation secondary to catecholaminesecreting pheochromocytoma?, Clin Nucl. Med. 37 (5) (2012) e119-e120.

[18] Q. Wang, M. Zhang, G. Ning, W. Gu, T. Su, M. Xu, B. Li, W. Wang, Brown adipose tissue in humans is activated by elevated plasma catecholamines levels and is inversely related to central obesity, PLoS One 6 (6) (2011) e21006.

[19] K. Fearon, F. Strasser, S.D. Anker, I. Bosaeus, E. Bruera, R.L. Fainsinger, A. Jatoi, C. Loprinzi, N. MacDonald, G. Mantovani, M. Davis, M. Muscaritoli, F. Ottery, L. Radbruch, P. Ravasco, D. Walsh, A. Wilcock, S. Kaasa, V.E. Baracos, Definition and classification of cancer cachexia: an international consensus, Lancet Oncol. 12 (5) (2011) 489-495.

[20] E.S. Bachman, H. Dhillon, C.-Y. Zhang, S. Cinti, A.C. Bianco, B.K. Kobilka, B.B. Lowell, BetaAR signaling required for diet-induced thermogenesis and obesity resistance, Science 297 (5582) (2002) 843-845.

[21] A.M. Cypess, L.S. Weiner, C. Roberts-Toler, E. Franquet Elía, S.H. Kessler, P.A. Kahn, J. English, K. Chatman, S.A. Trauger, A. Doria, G.M. Kolodny, Activation of human brown adipose tissue by a $\beta 3$-adrenergic receptor agonist, Cell Metab. 21 (1) (2015) 33-38.

[22] M.J. Hanssen, A.A. van der Lans, B. Brans, J. Hoeks, K.M. Jardon, G. Schaart, F. M. Mottaghy, P. Schrauwen, W.D. van Marken Lichtenbelt, Short-term cold acclimation recruits brown adipose tissue in obese humans, Diabetes (2016).

[23] Y. Le Marchand-Brustel, C. Olichon-Berthe, T. Grémeaux, J.F. Tanti, N. Rochet, E. Van Obberghen, Glucose transporter in insulin sensitive tissues of lean and obese mice. Effect of the thermogenic agent BRL 26830A, Endocrinology 127 (6) (1990) 2687-2695.

[24] T. Santalucía, M. Camps, A. Castelló, P. Muñoz, A. Nuel, X. Testar, M. Palacin, A. Zorzano, Developmental regulation of GLUT-1 (erythroid/Hep G2) and GLUT4 (muscle/fat) glucose transporter expression in rat heart, skeletal muscle, and brown adipose tissue, Endocrinology 130 (2) (1992) 837-846.

[25] B. Cannon, J. Nedergaard, Cultures of adipose precursor cells from brown adipose tissue and of clonal brown-adipocyte-like cell lines, Methods Mol. Biol. 155 (2001) 213-224.

[26] M.G. Buckley, E.A. Rath, Regulation of fatty acid synthesis and malonyl-CoA content in mouse brown adipose tissue in response to cold-exposure, starvation or re-feeding, Biochem J 243 (2) (1987) 437-442.

[27] A.C. Darnley, C.A. Carpenter, E.D. Saggerson, Changes in activities of some enzymes of glycerolipid synthesis in brown adipose tissue of cold-acclimated rats, Biochem. J. 253 (2) (1988) 351-355.

[28] X.X. Yu, D.A. Lewin, W. Forrest, S.H. Adams, Cold elicits the simultaneous induction of fatty acid synthesis and beta-oxidation in murine brown adipose tissue: prediction from differential gene expression and confirmation in vivo, FASEB J. 16 (2) (2002) 155-168.

[29] K.L. Townsend, Y.-H. Tseng, Brown fat fuel utilization and thermogenesis, Trends Endocrinol. Metab. 25 (4) (2014) 168-177.

[30] H. Aquila, T.A. Link, M. Klingenberg, The uncoupling protein from brown fat mitochondria is related to the mitochondrial ADP/ATP carrier. Analysis of sequence homologies and of folding of the protein in the membrane, EMBO J. 4 (9) (1985) 2369-2376. 
[31] F. Bouillaud, J. Weissenbach, D. Ricquier, Complete cDNA-derived amino acid sequence of rat brown fat uncoupling protein, J. Biol. Chem. 261 (4) (1986) 1487-1490.

[32] G.M. Heaton, R.J. Wagenvoord, A. Kemp, D.G. Nicholls, Brown-adipose-tissue mitochondria: photoaffinity labelling of the regulatory site of energy dissipation, Eur. J. Biochem. 82 (2) (1978) 515-521.

[33] R.G. Ridley, H.V. Patel, G.E. Gerber, R.C. Morton, K.B. Freeman, Complete nucleotide and derived amino acid sequence of cDNA encoding the mitochondrial uncoupling protein of rat brown adipose tissue: lack of a mitochondrial targeting presequence, Nucleic Acids Res. 14 (10) (1986) 4025-4035.

[34] S. Enerbäck, A. Jacobsson, E.M. Simpson, C. Guerra, H. Yamashita, M.E. Harper L.P. Kozak, Mice lacking mitochondrial uncoupling protein are cold-sensitive but not obese, Nature 387 (6628) (1997) 90-94.

[35] C. Beermann, J. Jelinek, T. Reinecker, A. Hauenschild, G. Boehm, H.-U. Klör, Short term effects of dietary medium-chain fatty acids and n-3 long-chain polyunsaturated fatty acids on the fat metabolism of healthy volunteers, Lipids Health Dis 2 (2003) 10.

[36] A. Fedorenko, P.V. Lishko, Y. Kirichok, Mechanism of fatty-acid-dependent UCP1 uncoupling in brown fat mitochondria, Cell 151 (2) (2012) 400-413.

[37] M. Klingenberg, Wanderings in bioenergetics and biomembranes, Biochim. Biophys. Acta 1797 (6-7) (2010) 579-594.

[38] D.G. Nicholls, The physiological regulation of uncoupling proteins, Biochim. Biophys. Acta 1757 (5-6) (2006) 459-466.

[39] D.G. Nicholls, R.M. Locke, Thermogenic mechanisms in brown fat, Physiol. Rev. 64 (1) (1984) 1-64.

[40] I.G. Shabalina, A. Jacobsson, B. Cannon, J. Nedergaard, Native UCP1 displays simple competitive kinetics between the regulators purine nucleotides and fatty acids, J. Biol. Chem. 279 (37) (2004) 38236-38248.

[41] E. Rial, M.M. González-Barroso, Physiological regulation of the transport activity in the uncoupling proteins UCP1 and UCP2, Biochim. Biophys. Acta 1504 (1) (2001) 70-81.

[42] S.B. Prusiner, B. Cannon, O. Lindberg, Oxidative metabolism in cells isolated from brown adipose tissue. 1. Catecholamine and fatty acid stimulation of respiration, Eur. J. Biochem. 6 (1) (1968) 15-22.

[43] N. Reed, J.N. Fain, Potassium-dependent stimulation of respiration in brown fat cells by fatty acids and lipolytic agents, J. Biol. Chem. 243 (23) (1968) 6077-6083.

[44] J.E. Schaffer, H.F. Lodish, Expression cloning and characterization of a novel adipocyte long chain fatty acid transport protein, Cell 79 (3) (1994) 427-436.

[45] P.P.S.J. Khedoe, G. Hoeke, S. Kooijman, W. Dijk, J.T. Buijs, S. Kersten, L.M. Havekes, P.S. Hiemstra, J.F.P. Berbée, M.R. Boon, P.C.N. Rensen, Brown adipose tissue takes up plasma triglycerides mostly after lipolysis, J. Lipid Res. 56 (1) (2015) 51-59.

[46] A. Bartelt, O.T. Bruns, R. Reimer, H. Hohenberg, H. Ittrich, K. Peldschus, M.G. Kaul, U.I. Tromsdorf, H. Weller, C. Waurisch, A. Eychmüller, P.L.S.M. Gordts, F. Rinninger, K. Bruegelmann, B. Freund, P. Nielsen, M. Merkel, J. Heeren, Brown adipose tissue activity controls triglyceride clearance, Nat. Med. 17 (2) (2011) 200-205.

[47] L. Eiselein, D.W. Wilson, M.W. Lamé, J.C. Rutledge, Lipolysis products from triglyceride-rich lipoproteins increase endothelial permeability, perturb zonula occludens-1 and F-actin, and induce apoptosis, Am J Physiol Heart Circ Physiol 292 (6) (2007) H2745-H2753.

[48] H. Doege, A. Stahl, Protein-mediated fatty acid uptake: novel insights from in vivo models, Physiology (Bethesda) 21 (2006) 259-268.

[49] S.M. Labbé, A. Caron, I. Bakan, M. Laplante, A.C. Carpentier, R. Lecomte, D. Richard, In vivo measurement of energy substrate contribution to coldinduced brown adipose tissue thermogenesis, FASEB J. 29 (5) (2015) 20462058.

[50] C.T. Coburn, T. Hajri, A. Ibrahimi, N.A. Abumrad, Role of CD36 in membrane transport and utilization of long-chain fatty acids by different tissues, J. Mol. Neurosci. 16 (2-3) (2001) 117-121. discussion 151-157.

[51] A. Stahl, A current review of fatty acid transport proteins (SLC27), Pflugers Arch. 447 (5) (2004) 722-727.

[52] H.C. Chiu, A. Kovacs, D.A. Ford, F.F. Hsu, R. Garcia, P. Herrero, J.E. Saffitz, J.E. Schaffer, A novel mouse model of lipotoxic cardiomyopathy, J. Clin. Invest. 107 (7) (2001) 813-822.

[53] M. Putri, M.R.A.A. Syamsunarno, T. Iso, A. Yamaguchi, H. Hanaoka, H. Sunaga, N. Koitabashi, H. Matsui, C. Yamazaki, S. Kameo, Y. Tsushima, T. Yokoyama, H. Koyama, N.A. Abumrad, M. Kurabayashi, CD36 is indispensable for thermogenesis under conditions of fasting and cold stress, Biochem. Biophys. Res. Commun. 457 (4) (2015) 520-525.

[54] I.J. Goldberg, R.H. Eckel, N.A. Abumrad, Regulation of fatty acid uptake into tissues: lipoprotein lipase- and CD36-mediated pathways, J. Lipid Res. 50 (Suppl) (2009) S86-S90.

[55] P. Tvrdik, A. Asadi, L.P. Kozak, J. Nedergaard, B. Cannon, A. Jacobsson, Cig30, a mouse member of a novel membrane protein gene family, is involved in the recruitment of brown adipose tissue, J. Biol. Chem. 272 (50) (1997) 3173831746.

[56] C.N. Hales, J.P. Luzio, K. Siddle, Hormonal control of adipose-tissue lipolysis, Biochem. Soc. Symp. 43 (1978) 97-135.

[57] V. Mohamed-Ali, J.H. Pinkney, S.W. Coppack, Adipose tissue as an endocrine and paracrine organ, Int. J. Obes. Relat. Metab. Disord. 22 (12) (1998) 11451158.

[58] G. Ailhaud, Adipose tissue as an endocrine organ, Int. J. Obes. Relat. Metab. Disord. 24 (Suppl 2) (2000) S1-S3.
[59] P. Trayhurn, J.H. Beattie, Physiological role of adipose tissue: white adipose tissue as an endocrine and secretory organ, Proc. Nutr. Soc. 60 (3) (2001) 329_ 339.

[60] J.A. Timmons, K. Wennmalm, O. Larsson, T.B. Walden, T. Lassmann, N. Petrovic, D.L. Hamilton, R.E. Gimeno, C. Wahlestedt, K. Baar, J. Nedergaard, B. Cannon, Myogenic gene expression signature establishes that brown and white adipocytes originate from distinct cell lineages, Proc. Natl. Acad. Sci. U. S.A. 104 (11) (2007) 4401-4406.

[61] J. Wu, P. Cohen, B.M. Spiegelman, Adaptive thermogenesis in adipocytes: is beige the new brown?, Genes Dev 27 (3) (2013) 234-250.

[62] L. Sidossis, S. Kajimura, Brown and beige fat in humans: thermogenic adipocytes that control energy and glucose homeostasis, J Clin Invest 125 (2) (2015) 478-486.

[63] T. Gnad, S. Scheibler, I. von Kügelgen, C. Scheele, A. Kilić, A. Glöde, L.S Hoffmann, L. Reverte-Salisa, P. Horn, S. Mutlu, A. El-Tayeb, M. Kranz, W. Deuther-Conrad, P. Brust, M.E. Lidell, M.J. Betz, S. Enerbäck, J. Schrader, G.G. Yegutkin, C.E. Müller, A. Pfeifer, Adenosine activates brown adipose tissue and recruits beige adipocytes via A2A receptors, Nature 516 (7531) (2014) 395-399.

[64] S. Collins, B-Adrenoceptor Signaling Networks in Adipocytes for Recruiting Stored Fat and Energy Expenditure, Front. Endocrinol. (Lausanne) 2 (2011) 102.

[65] L.S. Sidossis, C. Porter, M.K. Saraf, E. Børsheim, R.S. Radhakrishnan, T. Chao, A. Ali, M. Chondronikola, R. Mlcak, C.C. Finnerty, H.K. Hawkins, T. ToliverKinsky, D.N. Herndon, Browning of Subcutaneous White Adipose Tissue in Humans after Severe Adrenergic Stress, Cell Metab. 22 (2) (2015) 219-227.

[66] K.D. Nguyen, Y. Qiu, X. Cui, Y.P.S. Goh, J. Mwangi, T. David, L. Mukundan, F. Brombacher, R.M. Locksley, A. Chawla, Alternatively activated macrophages produce catecholamines to sustain adaptive thermogenesis, Nature 480 (7375) (2011) 104-108.

[67] Y. Qiu, K.D. Nguyen, J.I. Odegaard, X. Cui, X. Tian, R.M. Locksley, R.D. Palmiter, A. Chawla, Eosinophils and type 2 cytokine signaling in macrophages orchestrate development of functional beige fat, Cell 157 (6) (2014) 12921308.

[68] P. Boström, J. Wu, M.P. Jedrychowski, A. Korde, L. Ye, J.C. Lo, K.A. Rasbach, E.A Boström, J.H. Choi, J.Z. Long, S. Kajimura, M.C. Zingaretti, B.F. Vind, H. Tu, S. Cinti, K. Højlund, S.P. Gygi, B.M. Spiegelman, A PGC1- $\alpha$-dependent myokine that drives brown-fat-like development of white fat and thermogenesis, Nature 481 (7382) (2012) 463-468.

[69] P. Lee, J.D. Linderman, S. Smith, R.J. Brychta, J. Wang, C. Idelson, R.M. Perron, C. D. Werner, G.Q. Phan, U.S. Kammula, E. Kebebew, K. Pacak, K.Y. Chen, F.S. Celi, Irisin and FGF21 are cold-induced endocrine activators of brown fat function in humans, Cell Metab. 19 (2) (2014) 302-309.

[70] S. Kir, J.P. White, S. Kleiner, L. Kazak, P. Cohen, V.E. Baracos, B.M. Spiegelman, Tumour-derived PTH-related protein triggers adipose tissue browning and cancer cachexia, Nature 513 (7516) (2014) 100-104.

[71] W.T. Festuccia, P.-G. Blanchard, Y. Deshaies, Control of Brown Adipose Tissue Glucose and Lipid Metabolism by PPAR $\gamma$, Front. Endocrinol. (Lausanne) 2 (2011) 84 .

[72] M. Laplante, W.T. Festuccia, G. Soucy, P.-G. Blanchard, A. Renaud, J.P. Berger, G. Olivecrona, Y. Deshaies, Tissue-specific postprandial clearance is the major determinant of PPARgamma-induced triglyceride lowering in the rat, Am. J. Physiol. Regul. Integr. Comp. Physiol. 296 (1) (2009) R57-R66.

[73] R. Savonen, M. Hiden, M. Hultin, R. Zechner, S. Levak-Frank, G. Olivecrona, T. Olivecrona, The tissue distribution of lipoprotein lipase determines where chylomicrons bind, J. Lipid Res. 56 (3) (2015) 588-598.

[74] M. Bauwens, R. Wierts, B. van Royen, J. Bucerius, W. Backes, F. Mottaghy, B. Brans, Molecular imaging of brown adipose tissue in health and disease, Eur. J. Nucl. Med. Mol. Imaging 41 (4) (2014) 776-791.

[75] T.R. DeGrado, H.H. Coenen, G. Stocklin, 14(R, S)-[18F]fluoro-6-thiaheptadecanoic acid (FTHA): evaluation in mouse of a new probe of myocardial utilization of long chain fatty acids, J. Nucl. Med. 32 (10) (1991) 1888-1896.

[76] S.M. Labbé, T. Grenier-Larouche, E. Croteau, F. Normand-Lauzière, F. Frisch, R. Ouellet, B. Guérin, E.E. Turcotte, A.C. Carpentier, Organ-specific dietary fatty acid uptake in humans using positron emission tomography coupled to computed tomography, Am. J. Physiol. Endocrinol. Metab. 300 (3) (2011) E445-E453.

[77] R. Hovik, H. Osmundsen, R. Berge, A. Aarsland, S. Bergseth, J. Bremer, Effects of thia-substituted fatty acids on mitochondrial and peroxisomal betaoxidation. Studies in vivo and in vitro, Biochem. J. 270 (1) (1990) 167-173.

[78] S. Skrede, M. Narce, S. Bergseth, J. Bremer, The effects of alkylthioacetic acids (3-thia fatty acids) on fatty acid metabolism in isolated hepatocytes, Biochim. Biophys. Acta 1005 (3) (1989) 296-302.

[79] V. Ouellet, S.M. Labbé, D.P. Blondin, S. Phoenix, B. Guérin, F. Haman, E.E. Turcotte, D. Richard, A.C. Carpentier, Brown adipose tissue oxidative metabolism contributes to energy expenditure during acute cold exposure in humans, J Clin Invest 122 (2) (2012) 545-552.

[80] S. Baba, H.A. Jacene, J.M. Engles, H. Honda, R.L. Wahl, CT Hounsfield units of brown adipose tissue increase with activation: preclinical and clinical studies, J. Nucl. Med. 51 (2) (2010) 246-250.

[81] K. Yamasaki, S. Zhao, M. Nishimura, Y. Zhao, W. Yu, Y. Shimizu, K.-I. Nishijima, N. Tamaki, H. Takeda, Y. Kuge, Radiolabeled BMIPP for imaging hepatic fatty acid metabolism: evaluation of hepatic distribution and metabolism in mice at various metabolic statuses induced by fasting in comparison with palmitic acid, Mol. Imaging 14 (2015). 
[82] N. Tamaki, M. Kawamoto, N. Takahashi, Y. Yonekura, Y. Magata, T. Torizuka, R. Nohara, H. Kambara, J. Konishi, Assessment of myocardial fatty acid metabolism with positron emission tomography at rest and during dobutamine infusion in patients with coronary artery disease, Am. Heart J. 125 (3) (1993) 702-710.

[83] H.R. Schelbert, E. Henze, H. Sochor, R.G. Grossman, S.C. Huang, J.R. Barrio, M. Schwaiger, M.E. Phelps, Effects of substrate availability on myocardial C-11 palmitate kinetics by positron emission tomography in normal subjects and patients with ventricular dysfunction, Am. Heart J. 111 (6) (1986) 1055-1064.

[84] H.R. Schelbert, Myocardial ischemia and clinical applications of positron emission tomography, Am. J. Cardiol. 64 (9) (1989) 46E-53E.

[85] M. Bucci, A.C. Karmi, P. Iozzo, B.A. Fielding, A. Viljanen, R.M. Badeau, R. Borra, V. Saunavaara, T. Pham, J.C. Hannukainen, K. Kalliokoski, M. HaaparantaSolin, T. Viljanen, R. Parkkola, K.N. Frayn, P. Nuutila, Enhanced fatty acid uptake in visceral adipose tissue is not reversed by weight loss in obese individuals with the metabolic syndrome, Diabetologia 58 (1) (2015) 158164.

[86] Q. Lin, H. Luo, F. Mokler, A.L. Beets, K.R. Ambrose, D.W. McPherson, J. Kropp, F. F. Knapp, Effects of configuration on the myocardial uptake of radioiodinated 3(R)-BMIPP and 3(S)-BMIPP in rats, J. Nucl. Med. 38 (9) (1997) 1434-1441.

[87] J. Mertens, J. Eersels, W. Vanryckeghem, New high yield $\mathrm{Cu}(\mathrm{I})$ assisted ${ }^{123} \mathrm{I}$ radioiodination of 15 ( $p$-I-phenyl)-9-methyl pentadecanoic acid, a potential myocardial tracer, Eur. J. Nucl. Med. 13 (3) (1987) 159-160.

[88] M.R.A.A. Syamsunarno, T. Iso, A. Yamaguchi, H. Hanaoka, M. Putri, M Obokata, H. Sunaga, N. Koitabashi, H. Matsui, K. Maeda, K. Endo, Y. Tsushima, T. Yokoyama, M. Kurabayashi, Fatty acid binding protein 4 and 5 play crucial role in thermogenesis under the conditions of fasting and cold stress, PLoS One 9 (6) (2014) e90825.

[89] N.D. Poe, G.D. Robinson Jr., L.S. Graham, N.S. MacDonald, Experimental basis of myocardial imaging with ${ }^{123}$ I-labeled hexadecenoic acid, J. Nucl. Med. 17 (12) (1976) 1077-1082.

[90] N.D. Poe, G.D. Robinson, F.W. Zielinski, W.R. Cabeen, J.W. Smith, A.S. Gomes, Myocardial imaging with 123I-hexadecenoic acid, Radiology 124 (2) (1977) 419-424.

[91] G. Notohamiprodjo, A. Schmid, G. Spohr, K. Vyska, L.E. Feinendegen, Comparison of 11-C-Palmitic Acid (CPA), and 123-I-heptadecanoic acid (IHA) turnover in human heart, J. Nucl. Med. 26 (5) (1985) 88.

[92] J.R. Corbett, Fatty acids for myocardial imaging, Semin. Nucl. Med. 29 (3) (1999) 237-258.

[93] E. Livni, D.R. Elmaleh, S. Levy, G.L. Brownell, W.H. Strauss, Beta-methyl[111C]heptadecanoic acid: a new myocardial metabolic tracer for positron emission tomography, J. Nucl. Med. 23 (2) (1982) 169-175.

[94] A.E. Thumser, J. Storch, Characterization of a BODIPY-labeled fluorescent fatty acid analogue. Binding to fatty acid-binding proteins, intracellular localization, and metabolism, Mol. Cell. Biochem. 299 (1-2) (2007) 67-73.

[95] H. Wang, E. Wei, A.D. Quiroga, X. Sun, N. Touret, R. Lehner, Altered lipid droplet dynamics in hepatocytes lacking triacylglycerol hydrolase expression, Mol. Biol. Cell 21 (12) (2010) 1991-2000.

[96] E. Dubikovskaya, R. Chudnovskiy, G. Karateev, H.M. Park, A. Stahl, Measurement of long-chain fatty acid uptake into adipocytes, Methods Enzymol. 538 (2014) 107-134.

[97] J. Kasurinen, A novel fluorescent fatty acid, 5-methyl-BDY-3-dodecanoic acid is a potential probe in lipid transport studies by incorporating selectively to lipid classes of BHK cells, Biochem. Biophys. Res. Commun. 187 (3) (1992) 1594-1601.

[98] T.R. DeGrado, S. Wang, J.E. Holden, R.J. Nickles, M. Taylor, C.K. Stone, Synthesis and preliminary evaluation of (18)F-labeled 4-thia palmitate as a PET trace of myocardial fatty acid oxidation, Nucl. Med. Biol. 27 (3) (2000) 221-231.

[99] L.R. Jones, E.A. Goun, R. Shinde, J.B. Rothbard, C.H. Contag, P.A. Wender Releasable luciferin-transporter conjugates: tools for the real-time analysis of cellular uptake and release, J. Am. Chem. Soc. 128 (20) (2006) 6526-6527.

[100] A.H. Henkin, A.S. Cohen, E.A. Dubikovskaya, H.M. Park, G.F. Nikitin, M.G. Auzias, M. Kazantzis, C.R. Bertozzi, A. Stahl, Real-time noninvasive imaging of fatty acid uptake in vivo, ACS Chem. Biol. 7 (11) (2012) 1884-1891.

[101] D.E. Jenkins, Y. Oei, Y.S. Hornig, S.F. Yu, J. Dusich, T. Purchio, P.R. Contag Bioluminescent imaging (BLI) to improve and refine traditional murine models of tumor growth and metastasis, Clin. Exp. Metastasis 20 (8) (2003) $733-744$.

[102] O.T. Bruns, H. Ittrich, K. Peldschus, M.G. Kaul, U.I. Tromsdorf, J. Lauterwasser, M.S. Nikolic, B. Mollwitz, M. Merkel, N.C. Bigall, S. Sapra, R. Reimer, H. Hohenberg, H. Weller, A. Eychmüller, G. Adam, U. Beisiegel, J. Heeren, Realtime magnetic resonance imaging and quantification of lipoprotein metabolism in vivo using nanocrystals, Nat. Nanotechnol. 4 (3) (2009) 193201.

[103] K. Grimpo, M.N. Völker, E.N. Heppe, S. Braun, J.T. Heverhagen, G. Heldmaier, Brown adipose tissue dynamics in wild-type and UCP1-knockout mice: in vivo insights with magnetic resonance, J. Lipid Res. 55 (3) (2014) 398-409.

[104] M. Holstila, K.A. Virtanen, T.J. Grönroos, J. Laine, V. Lepomäki, J. Saunavaara, I. Lisinen, M. Komu, J.C. Hannukainen, P. Nuutila, R. Parkkola, R.J.H. Borra, Measurement of brown adipose tissue mass using a novel dual-echo magnetic resonance imaging approach: a validation study, Metabolism 62 (8) (2013) 1189-1198.

[105] B.D. van Rooijen, A.A.J.J. van der Lans, B. Brans, J.E. Wildberger, F.M. Mottaghy, P. Schrauwen, W.H. Backes, W.D. van Marken, Lichtenbelt, Imaging coldactivated brown adipose tissue using dynamic T2*-weighted magnetic resonance imaging and 2-deoxy-2-[18F]fluoro-D-glucose positron emission tomography, Invest. Radiol. 48 (10) (2013) 708-714.

[106] R.T. Branca, W.S. Warren, In vivo brown adipose tissue detection and characterization using water-lipid intermolecular zero-quantum coherences, Magn. Reson. Med. 65 (2) (2011) 313-319.

[107] H.H. Hu, D.L. Smith, K.S. Nayak, M.I. Goran, T.R. Nagy, Identification of brown adipose tissue in mice with fat-water IDEAL-MRI, J. Magn. Reson. Imaging 31 (5) (2010) 1195-1202.

[108] A. Sbarbati, I. Cavallini, P. Marzola, E. Nicolato, F. Osculati, Contrast-enhanced MRI of brown adipose tissue after pharmacological stimulation, Magn. Reson. Med. 55 (4) (2006) 715-718.

[109] A. Khanna, R.T. Branca, Detecting brown adipose tissue activity with BOLD MRI in mice, Magn. Reson. Med. 68 (4) (2012) 1285-1290.

[110] A. Flynn, Q. Li, M. Panagia, A. Abdelbaky, M. MacNabb, A. Samir, A.M. Cypess, A.E. Weyman, A. Tawakol, M. Scherrer-Crosbie, Contrast-enhanced ultrasound: a novel noninvasive, nonionizing method for the detection of brown adipose tissue in humans, J. Am. Soc. Echocardiogr. 28 (10) (2015) 1247-1254.

[111] P.M. Gorter, A.S.R. van Lindert, A.M. de Vos, M.F.L. Meijs, Y. van der Graaf, P.A. Doevendans, M. Prokop, F.L.J. Visseren, Quantification of epicardial and pericoronary fat using cardiac computed tomography; reproducibility and relation with obesity and metabolic syndrome in patients suspected of coronary artery disease, Atherosclerosis 197 (2) (2008) 896-903.

[112] P. Maurovich-Horvat, K. Kallianos, L.-C. Engel, J. Szymonifka, C.S. Fox, U. Hoffmann, Q.A. Truong, Influence of pericoronary adipose tissue on local coronary atherosclerosis as assessed by a novel MDCT volumetric method, Atherosclerosis 219 (1) (2011) 151-157.

[113] A.A. Mahabadi, N. Reinsch, N. Lehmann, J. Altenbernd, H. Kälsch, R.M. Seibel, R. Erbel, S. Möhlenkamp, Association of pericoronary fat volume with atherosclerotic plaque burden in the underlying coronary artery: a segment analysis, Atherosclerosis 211 (1) (2010) 195-199.

[114] P.M. Gorter, A.M. de Vos, Y. van der Graaf, P.R. Stella, P.A. Doevendans, M.F.L. Meijs, M. Prokop, F.L.J. Visseren, Relation of epicardial and pericoronary fat to coronary atherosclerosis and coronary artery calcium in patients undergoing coronary angiography, Am. J. Cardiol. 102 (4) (2008) 380-385.

[115] O. Stein, R.O. Scow, Y. Stein, FFA-3H uptake by perfused adipose tissue: electron microscopic autoradiographic study, Am. J. Physiol. 219 (2) (1970) 510-518.

[116] J.P. Kampf, D. Parmley, A.M. Kleinfeld, Free fatty acid transport across adipocytes is mediated by an unknown membrane protein pump, Am. J. Physiol. Endocrinol. Metab. 293 (5) (2007) E1207-E1214.

[117] D. Cupp, J.P. Kampf, A.M. Kleinfeld, Fatty acid-albumin complexes and the determination of the transport of long chain free fatty acids across membranes, Biochemistry 43 (15) (2004) 4473-4481.

[118] K.C. Hames, A. Vella, B.J. Kemp, M.D. Jensen, Free fatty acid uptake in humans with CD36 deficiency, Diabetes 63 (11) (2014) 3606-3614. 